\title{
Neogene Tectonics in Croatian Part of the Pannonian Basin and Reflectance in Hydrocarbon Accumulations
}

\author{
Tomislav Malvić ${ }^{1}$ and Josipa Velić ${ }^{2}$ \\ IINA-Industry of Oil Plc. E University of Zagreb, \\ Faculty of Min., Geol. and Petr. Eng., \\ ${ }^{2}$ University of Zagreb, Faculty of Mining, Geology and Petroleum Engineering, Zagreb, \\ Croatia
}

\section{Introduction}

The structural complex Croatian part (CPBS) of the Pannonian Basin System (PBS; Fig. 1) is regional known example of Neogene and Quaternary transtensional and transpressional tectonics (Royden, 1988; Velić, 2007). Tectonical and sedimentation features in this area are very well described in numerous publications and can be used as examples for interpretation of Upper Cenozoic geology in similar geological provinces in the world. Also, PBS is characterised with many hydrocarbon discoveries, making this basin system still one of the most important hydrocarbon province in Europe, including significant undiscovered reserves in subtle, satellite or simply smaller traps. CPBS covers entire SW/S part of PBS and is characterised with many features that are recognizable in other areas of basin. But as it is marginal southern part of that basinal system there are several unique tectonic characteristics. Also, CPBS is characterised with numerous hydrocarbon discoveries in rocks from Palaeozoic to Lower Pontian ages (Velić, 2007; Velić et al., 2002, 2008, 2010; Malvić, 2003). Structurally, hydrocarbon fields include compartmentalization controlled by fault system and lithological variations. These properties make some of field's structures in CPBS as classical examples of Neogene and Quaternary tectonics and hydrocarbon reservoirs in PBS as a whole.

Also, geology of SW margin of CPBS is characterised by contact with Dinarides, as the next regional geological province. This remarkable contact is very deep fault zone called Periadriatic-Vardar lineament (Fig. 1). During Neogene it was the margin of Pannonian (as part of Paratethys) Sea and later Sava Lake. This sea or lake, comprised several Neogene depositional areas in CPBS, which is surrounded with many inland and highland areas (Malvić, 2003; Velić, 2007; Vrbanac, 2002; Vrbanac et al., 2010). As it is seen CPBS has relatively isolated position in PBS, thanks to numerous mountains which existed as uplifted palaeorelief through entire Neogene (like Medvednica, Kalnik, Moslavačka gora, Papuk, Psunj, Krndija and Dilj Mts.). The elongated shape of depressions, which clearly follows the SW margin of PBS, indicated on relatively shallow environment with irregular palaeo-cost line. All these facts asked for many detail studies of Neogene and Quaternary evolution of $\mathrm{CPBS}$ and its reflectance in hydrocarbon genesis, migration and accumulation, what had 
been done through several decades and still are object of scientific interest. Analysis presented here is some kind of review of and contribution in our present knowledge of that area.

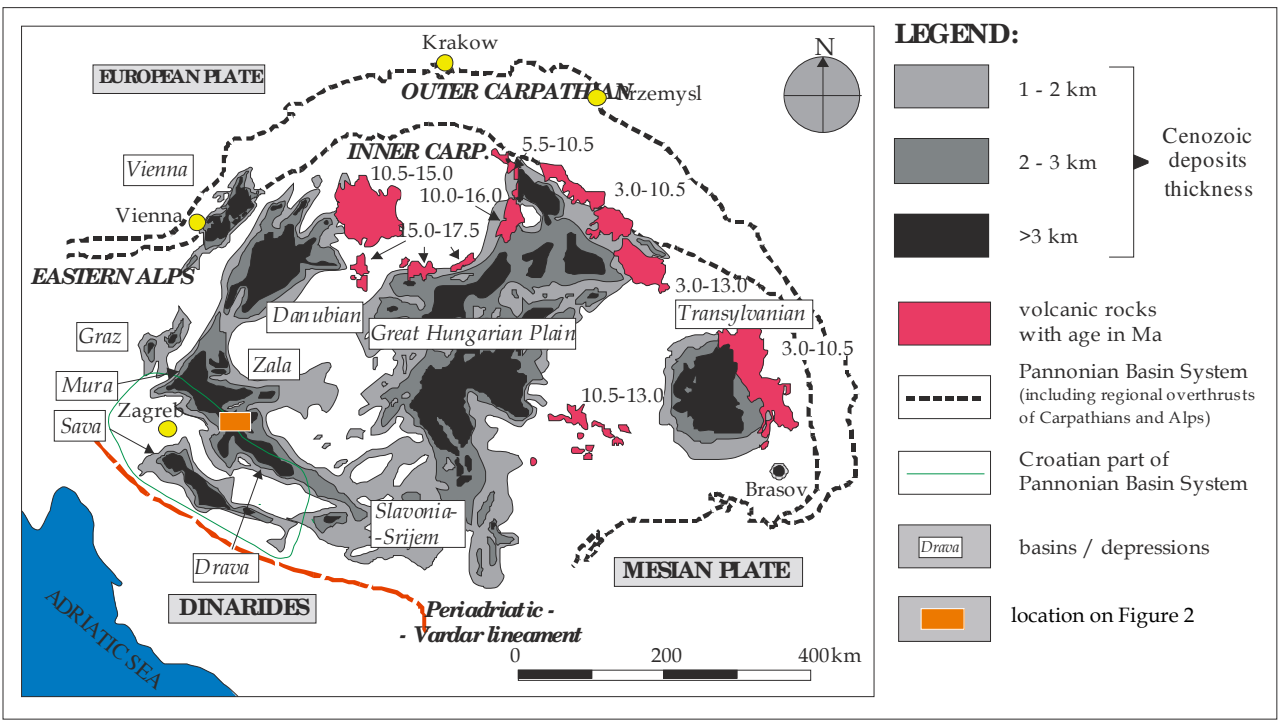

Fig. 1. Geotectonic units of the Pannonian Basin System (modified after Royden, 1988)

\section{Neogene tectonics in Croatian part of the Pannonian Basin system}

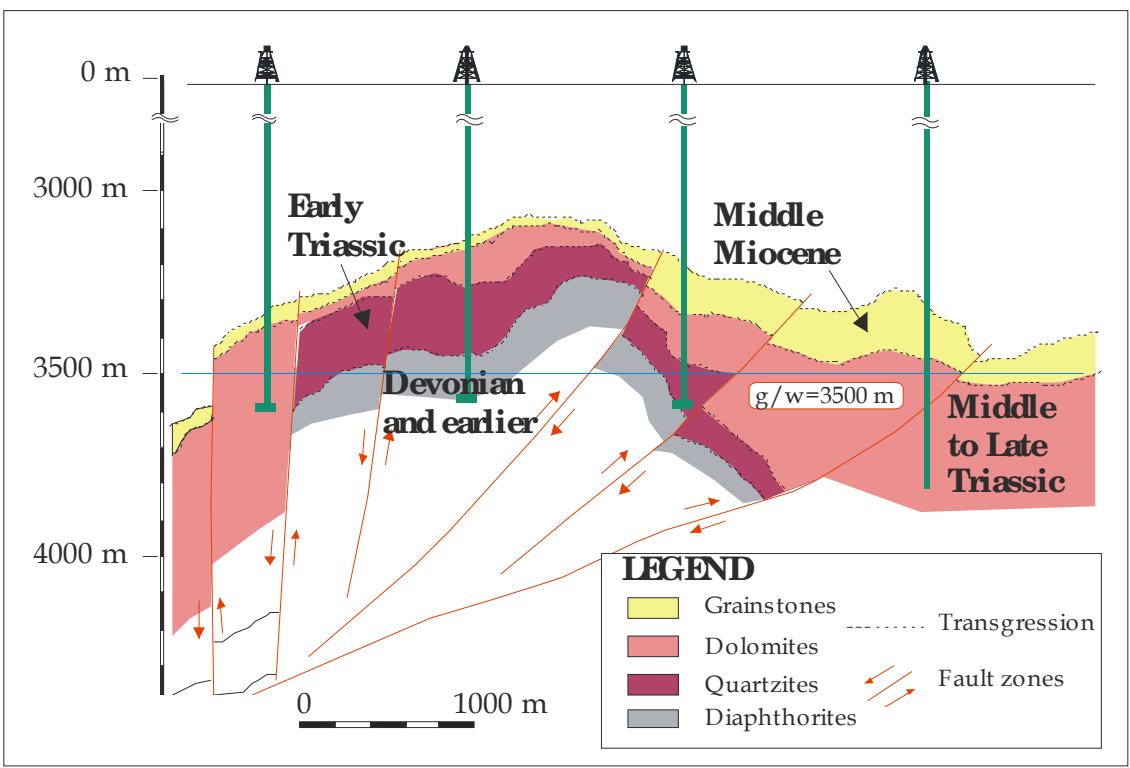

Fig. 2. Typical large, faulted anticline in the Drava Depression 
The oldest, still recognisable, tectonic displacements are the results of Palaeozoic and Mesozoic orogenesis. Many Mesozoic deposits were eroded during the Palaeogene. Palaeozoic and Mesozoic rocks are separated by regional unconformities from Neogene sediments, but also inside Neogene sequence can be found some local unconformities. However, the chronostratigraphic units mostly have retained their original superpositional relations.

The present-day structures are developed in the Miocene, starting with extensional tectonics in opening of the PBS and uplifting of the Apennines and the Dinarides (Royden, 1988; Yilmaz et al., 1996). Middle Miocene was generally reflected in numerous extensional intrabasin strike-slip structures.

Such strike-slip structures regular started as negative flower structures in Middle (rarely Lower) and Late Miocene, but later in Pliocene and Quaternary were inverted in positive (Malvić and Velić, 2010). It assumed reactivation and changing character of many faults, especially main bordering structure faults, from normal to reverse (Fig. 2). Eventually, many such uplifted anticlines had been connected through mutual spill points in larger anticlinorium. The best example is the largest anticlinorium in CPBS, the large MolveKalinovac-Stari Gradac structure.

\subsection{Transtensional and transpressional phases in Neogene and Quaternary}

Royden (1988) and Rögl $(1996,1998)$ documented the ages of different Miocene episodes in the Pannonian area, establishing a scale used to categorize tectonic and sedimentation cycles. Tectonic extension in the PBS (probably sporadically also in CPBS) started in the Ottnangian (19.0 to 17.2 Ma; Haq \& Eysinga, 1998), locally accompanied by a marine transgression, often paralic environments and strike-slip displacements. Extension continued in the Karpatian (17.2 to 16.4 Ma; Haq \& Eysinga, 1998), when the some parts of CPBS possible were covered by brackish or marine sediments.

$1^{\text {st }}$ transtensional phase in CPBS maximal extension reached in the Badenian (16.4 to 13.0 Ma; Haq \& Eysinga, 1998), when strike-slip tectonics was main mechanism of structural development. Vrbanac (2002) described an extensive marine environment as dominant in CPBS during the Late Badenian, with several large mountains as islands. During extension, clastics sources were (a) siliciclastic basement rocks or (b) carbonates eroded by weathering of corallinaceaen sp. and briozoan sp. reefs (Malvić, 1998, 2003). This material was deposited in alluvial-fan environments. Coarse-grained sediments were deposited in the proximal part, and medium- and fine-grained sandstones in the middle or distal part such fans (Fig. 3). This explains the gradual decrease of porosity values in Middle Miocene facies in many field's structures, mostly toward SE (Fig. 5).

Middle Badenian sediments are coarse-grained breccia and breccia-conglomerates, representing important reservoir lithofacies for hydrocarbon accumulations. Sometimes these reservoirs can contain significant part of non-hydrocarbon components (mercury, $\mathrm{N}_{2}$, $\mathrm{CO}_{2}, \mathrm{H}_{2} \mathrm{~S}$, chlorides and mercaptans) like reservoir fluid in the Molve Field. It can be explained by geological complexity, reservoir thermodynamics and generation in carbonate rocks (Barić et al., 1991, 1998). Upper Badenian sediments are mostly fine-grained sandstones, siltstones and, at the top, limestones and calcitic marlstones. It is very hard to determined border between Badenian and Sarmatian due to lithological similarity. The Late Badenian generally represented a transition between extensional (transtensional) and postextensional phases in Northern Croatia (Pavelić, 2002). Generally, evolution of the Badenian 
environment was mostly controlled by palaeorelief of the pre-Neogene basement, erosion rate, stream power of alluvial fans and local tectonics.

Sarmatian was period of when 1st transpression in CPBS started. After series of transgressive-regressive cycles in the Badenian, it was followed by a overall regression during the Sarmatian (13.0 to $11.5 \mathrm{Ma}$; Haq \& Eysinga, 1998), typical for the Central Paratethys (e.g. Rögl \& Steininger, 1984; Kovač et al., 1997; Pavelić, 2001; Vrsaljko et al., 2006). This post-extensional phase was characterized by local thermal subsidence of the base of the Pannonian Basin. Extensional tectonics (dominantly strike-slip negative structures and normal faulting) were replaced by a compressional style (mostly reverse faulting) over almost the entire PBS. Tectonics still controlled sedimentation locally (Royden, 1988; Rögl \& Steininger, 1984; Pavelić, 2001, 2002), but the importance of alluvial fans significantly decreased. Sea level was lowered, salinity was reduced (existence of brackish environment) and, most importantly, the deep-water turbidites that originated in the Alps had been activated in some parts of PBS.

These turbidites were a much more abundant source of sediments in CPBS from the Early Pannonian to the Late Pontian, when almost completely replaced mechanism of relatively small alluvial fans. Sedimentation of organic-rich material (later often matured source rocks) continues from Late Badenian. These limestones, marly limestones and calcitic marls today can be found on the depths between $2000-4000 \mathrm{~m}$. Such source rocks also are commonly seals, causing long (10-15 km; Malvić, 2003) lateral migration as a favourable mechanism of hydrocarbon accumulating in CPBS.

In the Early Pannonian (11.5 to 9.3 Ma; Haq \& Eysinga, 1998) the $2^{\text {nd }}$ transtensional localized strike-slip tectonics took place in the PBS (Royden, 1988). In a large lacustrine, brackish and eventually fresh-water environment, characterised by depths up to several hundreds metres (Vrbanac et al., 2010), salinity was continuously reduced owing to fresh-water inflow and a lack of connection with other open-sea environments.

Turbidite currents of high-density were especially active in Late Pannonian (9.3 to 7.1 Ma; Haq \& Eysinga, 1998) and Early Pontian (7.1 to 6.3 Ma; Haq \& Eysinga, 1998) time. Significant quantities of clastics were transported from the Eastern Alps in CPBS through several turbidite events initiated by ramp-fault activity. Each depositional episode moved clastics over tens of kilometres, deposited them next to the tectonic ramp, and pushing sediments to a final depositional centres in the Mura, Sava, Drava and Slavonia-Srijem depressions to structurally determined areas. Successive turbidite events represented the dominant Late Miocene sedimentation mechanism in the Croatian depressions (Vrbanac, 2002). Turbiditic sequences were source of medium to fine-grained sandstones that represents the main reservoir lithofacies in CPBS. This mechanism was active periodically, interrupted typical hemipelagic sedimentation in lacustrine environment in CPBS. That resulted in monotonous alteration of sandstone and marlstone lithofacies through most of Pannonian and Pontian stages.

The Late Pontian (6.3-5.6 Ma), Pliocene and Quaternary (2.6 to 0.0 Ma) were period of $2^{\text {nd }}$ transpressional phase, when negative flower structures and faulted anticlines had been uplifted and hydrocarbons migrated in recent reservoirs. It was characterized by sporadically lacustrine, and mostly marsh, river and continental sediments (loess). Sedimentation took place in fresh lacustrine waters. This sedimentation represented periods of overall regression and reduction of the depositional area in final continental phase. The main described regional tectonical and depositional events in chronostratigraphical timescale are schematically given in Table 1. 


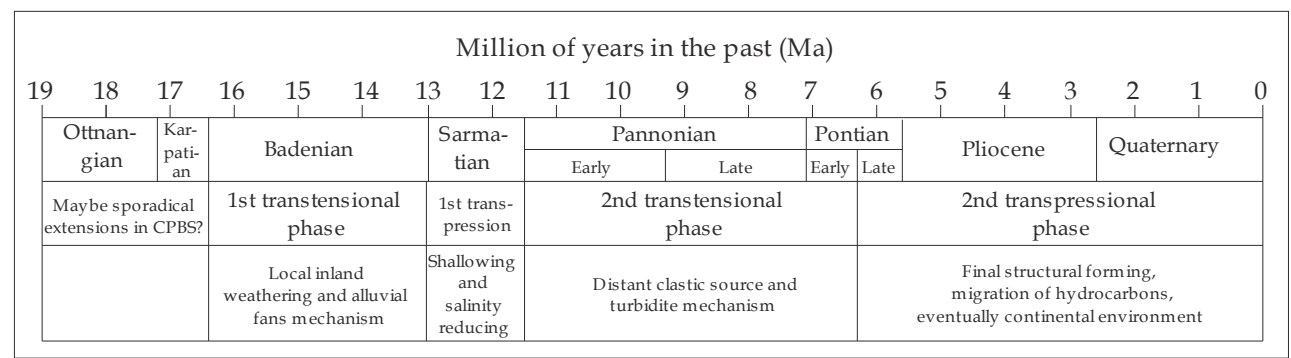

Table 1. Time-scale of the main tectonical and depositional events in Neogene and Quaternary in CPBS

\subsection{Neogene and Quaternary sedimentation through megacycles as genetic units}

Neogene and Quaternary sediments are divided in 3 megacycles (Velić et al. 2002, Velić 2007). Each is described by depth and age of sediments, trap types and petrophysical properties. These sediments can be also found as outcrops on hills of surrounding mountains, but only with approx. $3 \%$ of total volume, but the largest part is covered with Quaternary deposits (Velić, 2007). In marginal parts of CPBS depressions Neogene thickness ranges $500-1500 \mathrm{~m}$, and in central areas it could reach up to $3500 \mathrm{~m}$ in Slavonia-Srijem Depression, $5500 \mathrm{~m}$ in Sava and Mura Depressions and near $7000 \mathrm{~m}$ in Drava Depression.

Neogene sediments are often cyclic. Such regularities and lithological characteristics were reason for selection 3 megacycles, and their division to lithostratigraphic formations and members. Each megacycles included rocks deposited in one super cycle of relative sea level changing, which is firstly characterised by gradually increasing, and secondly by relative abruptly decreasing of water depth (Mitchum, 1977). All megacycles are lithologically different, because they resulted from different transtensions and transpressions phases, different basins palaeorelief, as well as from eustatic and climate changes (Šimon, 1980).

\subsubsection{Lower and Middle Miocene $\left(1^{\text {st }}\right)$ megacycle}

The oldest megacycle lasted in Lower and (mostly) Middle Miocene, i.e. approx. $6.8 \mathrm{Ma}$ (geochronological data after Rögl, 1996). It is characterized by heterogenetic clastic lithologies. Lithostratigraphically, this megacycle includes Prečec Formation in the Sava Depression, Vukovar Formation in the eastern Drava and Slavonia-Srijem Depression, Moslavačka gora Formation in the western Drava Depression and Murska Sobota Formation (except uppermost part) in the Mura Depression.

These sediments are characterised by coarse-grained clastics (breccia, conglomerates or sandstones), fine-grained and pelitic clastics (clays, marls, calcitic marls, sandy and clayey marls with tuff intercalations) and carbonates (limestones, often Lithotamnium, and calcarenite sandstones). Some authors origin of tuffs and effusives in sediments of this age placed in Egerian and Egenburg (Pamić, 1997), and related sediments in Early Miocene paralic and transition environments. But Badenian is generally described as period when marine sedimentation took place everywhere in CPBS (e.g. Lučić et al., 2001, Vrbanac, 2006). Some new results located begging of all Neogene sedimentation in CPBS just in Badenian (Ćorić et al., 2009), what is today mostly accepted.

Heterogeneity of rocks is accompanied with large (and somewhere rapid) changes in thicknesses. For example, in the Sava and Drava Depressions thickness of these sediments 
can differ more than $2000 \mathrm{~m}$ on distance of 3-4 km. Generally, psamitic sediments of this megacycle are mostly deposited on margins as results of alluvial fans activity, and pelitic in central parts of depressions where normal basin plain sedimentation took place. As it was mentioned, pelitic sediments of this age are often source rocks (e.g. Troskot-Čorbić et al., 2009), including mature rocks from Upper Badenian to Lower Pannonian (2nd megacycle).

\subsubsection{Late Miocene $\left(2^{\text {nd }}\right)$ megacycle}

The second megacycle had Late Miocene age (Pannonian and Pontian). It includes sedimentary association of the Sava Group (Ivanić-Grad, Kloštar-Ivanić and Široko Polje Formations) in the Sava and western Drava Depressions, then Vinkovci and Vera Formations in the eastern Drava and Slavonia-Srijem Depressions and Lendava Formation and lower part of Mura Formation in the Mura Depression.

Deposition lasted approx. 5.9 Ma (Rögl, 1996). The oldest part is located deeper than $5000 \mathrm{~m}$ in Virovitica area. Generally, it is represented by uniform sequences (or homogeneous alteration) of sandstones (subgrauwacke and calcarenite subgrauwacke), siltites and marls with transitional lithotypes. Sandstones are mostly grey coloured, dominantly with quartz, and rock clasts (mostly limestones), mica and feldspat. The Pannonian sediments are deposited in brackish and Pontian in fresh water lake environment. The thickness varies from approx. $2000 \mathrm{~m}$ (in small pull-aparts of Hrvatsko Zagorje Subdepression) to more than $4000 \mathrm{~m}$ in the deepest parts of the Drava Depression (Velić et al., 2002).

The maximal total thicknesses are proven in wells located in the central part of depressions, where is also proven the maximum of sandstone thicknesses. These sandstones gradually pinch out toward margins, where are laterally gradually changed in marls. Deposition had been active in lake environment mostly deeper than $200 \mathrm{~m}$ (Vrbanac et al., 2010), where low energy basin sedimentation had been interrupted with periodical turbidites, which direction had been determined by sub-water, basement palaeorelief.

The main sources of silt and sand particles were Eastern Alps. These clastics which had been several times re-deposited, and moved to tectonically instable slope or ramp and, after tectonical displacement, transported by turbidites in different parts of depressions (e.g. Velić et al., 2002; Vrbanac et al., 2010). Homogenous alteration of sandstones and marls in deeper parts is characterized by regional e-log markers (or key-beds) that are also chronostratigraphic border. These markers are regularly used in regional correlation of lithostratigraphic units in CPBS.

\subsubsection{Pliocene and Quaternary $\left(3^{\text {rd }}\right)$ megacycle}

The youngest is $1^{\text {st }}$ megacycle of Pliocene and Quaternary periods, which lasted approx. 5.6 Ma (Rögl, 1996.). There are described Lonja Formation in the Sava and western Drava Depressions, Vuka Formation in the eastern Drava and Slavonia-Srijem Depressions, and Mura Formation in the Mura Depression. This megacycle is lithologically represented by alteration of poorly consolidated sandstones and soft clay with rare lignite. Only in the deepest parts (below $500 \mathrm{~m}$ ) compaction can be enough strong for clayey limestones, marls and fine-grained sandstones. In the shallowest parts sediments are of gravels, loess and silts. Thickness can reach more than $1500 \mathrm{~m}$ in the Sava and $2200 \mathrm{~m}$ in the Drava Depression (Velić et al., 2002). All these sediments are product of mostly continental environments. 


\subsection{Main depositional mechanisms for reservoir rocks in Neogene}

Depositional systems through Neogene of CPBS can be considered through two main cycles when large part of clastic and reservoir lithofacies deposited, with different transport mechanisms and sources of clastic materials. The first one is period of Badenian that tectonically belongs to period of $1^{\text {st }}$ transtension in CPBS, and $3^{\text {rd }}$ megacycle. The second type of depositional mechanism had been active from Late Pannonian to Early Pontian, i.e. through period of $2^{\text {nd }}$ transtension and $2^{\text {nd }}$ megacycle.

\subsubsection{Depositional mechanism during Badenian ( $1^{\text {st }}$ transtension and $1^{\text {st }}$ megacycle)}

Sediments of Middle (maybe locally also Lower) Miocene in CPBS are common reservoir, seal and source rocks. These are the earliest sediments deposited during Neogene transgression covering the entire CPBS (Ćorić et al., 2009). These sequences embracing mostly the Badenian, Sarmatian and Lower Pannonian ages are mainly clastic rocks. Badenian started by coarse-grained alluvial sediments and Lower Pannonian finished by lacustric marls.

Marine environments (Vrbanac, 1996; Rögl, 1996, 1998; Ćorić et al., 2009) covered entire northern Croatia. Irregular, previously faulted and weathered, palaeorelief of Palaeozoic and Mesozoic basement resulted in significant depth differences and played important geomorphological role on the sea bottom. It is considered that large areas of present-day mountains in northern Croatia, like Medvednica, Kalnik, Moslavačka gora, Psunj and Papuk Mts., remained more or less isolated islands above the sea-level.

Palaeozoic rocks and basement gave siliciclastic and Mesozoic carbonate detritus for coarsegrained sediments in Badenian. Moreover, lithoral algae reefs were abundant in shallow marine environments, where such reefs (mostly Coralinacea and Briozoa origin) were eroded by sea currents, representing important source of carbonate clasts later re-deposited in potential reservoir rocks.

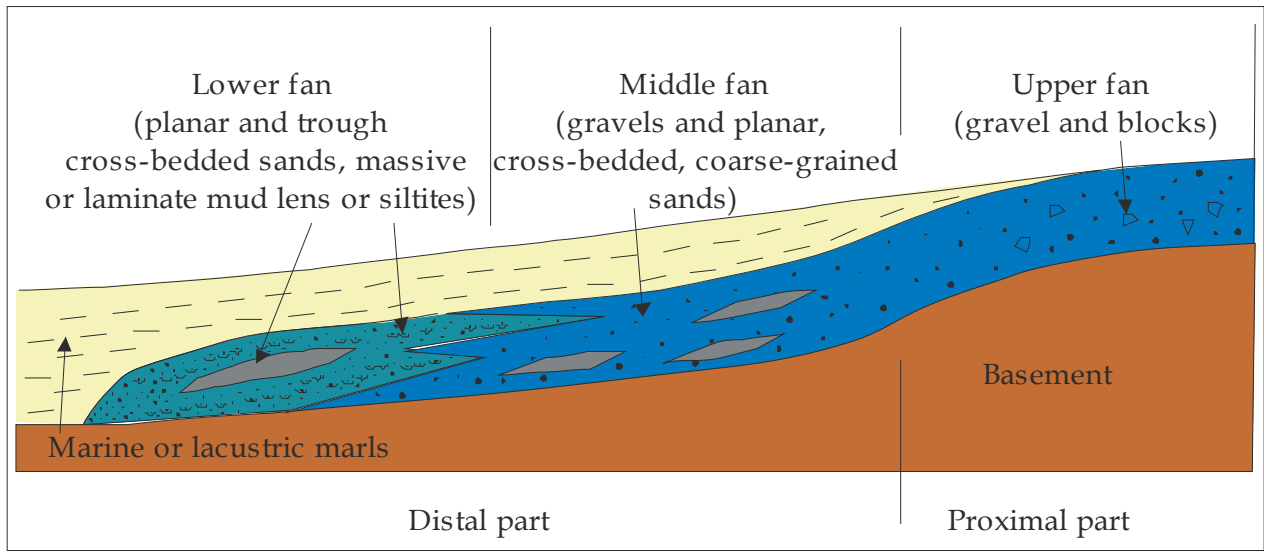

Fig. 3. Schematic review of typical alluvial fan and lithofacies distribution

The main mechanism that transported clastics in shallow sea encompassed alluvial fans, divided in proximal and distal parts (Malvić, 1998). Coarse-grained sediments, as promising reservoir lithofacies, were deposited in the proximal part (Fig. 3). Sometimes in such fans, especially in proximal part, can not be found carbonate clasts originated form reef 
organisms, what is indicator of strong erosion and high energy of fan. Mostly mediumgrained sands were deposited in the middle part of alluvial fan (Fig. 3). Sometimes their green colour, due to mica and chlorite minerals, is the indication of weak reductive environment in sea with normal salinity (Odin and Matter, 1981; Tišljar, 1993). Fine-grained sands and silts had been deposited in the lower part of alluvial fan (Fig. 3) and this sequence characterise a fan migration in time and space. Also, such vertical transition described change in brackish, shallow and stagnant environment of Upper Badenian. Badenian top is represented with marlstones and marly limestones deposited in stagnant and shallow (mostly up to $100 \mathrm{~m}$ deep) sea.

The typical Badenian erosional slope had been mapped in many hydrocarbon fields in the CPBS (Tišljar, 1993; Malvić, 2003, 2006). It comprises Middle Badenian reservoir rocks connected in one hydrodynamic unit by catalysed basement rocks along unconformities. Upper Badenian included seal rocks, which are sometimes also source rocks, and such pelitic sequence is often continued in Sarmatian and Early Pannonian.

One typical field structures, with Badenian reservoirs, located between major extensional faults and connected with basement buried hills, is shown on Fig. 4. The structural position and shape determined distribution of lithofacies and their thickness during Middle Miocene sedimentation. It is possible using maps of some geological reservoir variables like porosity (Fig. 5), thickness or depth for defining transition and spatial positions of different reservoir lithofacies (e.g. Malvić, 2006) as well as direction and energy of alluvial fan that had been active as mechanism for sedimentation of potential reservoir rocks.

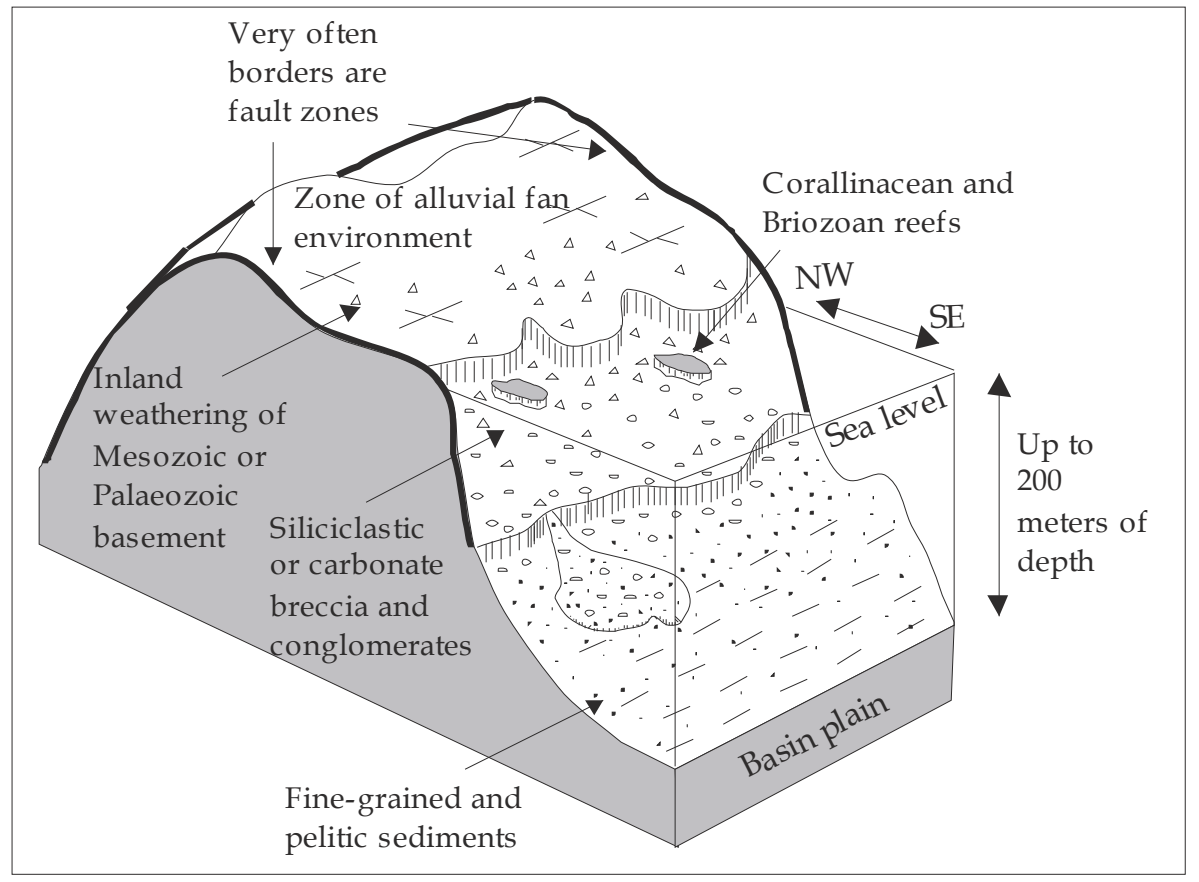

Fig. 4. Schematic review of typical depositional environment in Early Badenian (modified after Malvić, 2006) 
The coarse-grained sediments of alluvial fans have the great hydrocarbon potential, because they are, after few million years, often consolidated into good reservoir rocks, with significant primary porosity (more than $10 \%$ ). Such rocks are mostly overlain by pelitic seal deposits (resulted from distal fan or basin plain sedimentation) sometimes including organic rich source facies (kerogene type II and III, Barić et al., 1991, 1993). It means that Badenian sequences can often be described as complete petroleum systems, what is confirmed by large number of oil and gas discoveries in such sediments in entire CPBS (Velić, 2007).

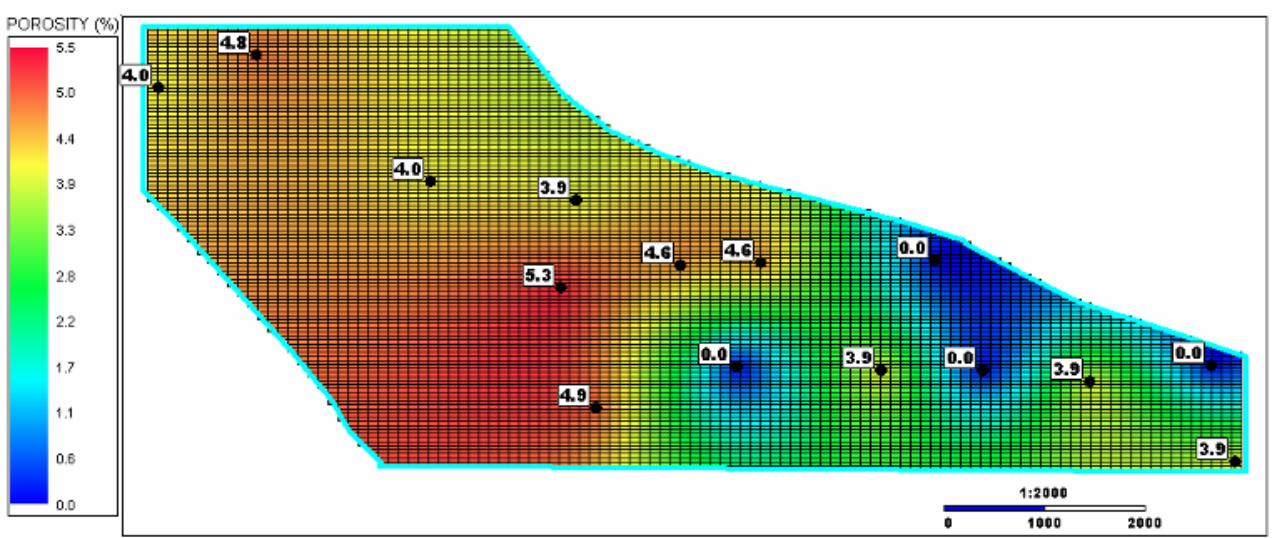

Fig. 5. Distribution of porosity in alluvial fan environment in Stari Gradac-Barcs Nyugat Field (from Malvić, 2006)

Alluvial environments are relatively short distribution area of few kilometres distance (Malvić, 1998), but they are also characterised by frequent changes of petrophysical properties due to local material source and depositional area. It means that Badenian lithofacies are characterised by heterogeneity of thickness and porosity already in small scale (within the range of several hundreds of meters).

It could be observed in Fig. 5, where palaeo-activity of proximal part of alluvial fan is observed on the NW of the Stari Gradac-Barcs Nyugat structure. That area contains coarsegrained sandstones with primary porosity. Those sandstones originated from uplifted Mesozoic basement located close to the NW margin of the structure (Fig. 6). It was weathered and eroded close to strike-slip depression opened just on SE along of the main bordering faults (strike NW-SE and WNW-ESE; Fig. 6).

The region of smaller (mostly lower than 3\%, what was cut-off for HC reserve calculation) porosities (Fig. 5) and larger thicknesses belong to distal part of alluvial fan, which through Badenian existed on the SW part of the structure shown on Fig. 6. Distal part was tectonically downlifted along the main fault of the NNE-SSW striking, located in the middle of structure (Fig. 6). Lithologically, this area is characterised by fine-grained planar and trough cross-bedded sands or basin-plain marls (Malvić, 2006).

Later, in the $1^{\text {st }}$ and especially $2^{\text {nd }}$ transpressional phase, entire structure was uplifted (changing of fault character) along the same main fault lines (NW-SE strike) that bordered the structure, which also changed fault character from normal to reverse. Described mechanism of alluvial fan lithofacies distribution and tectonic inversion is the most often geological mechanism of Middle Miocene reservoir forming in CPBS. 


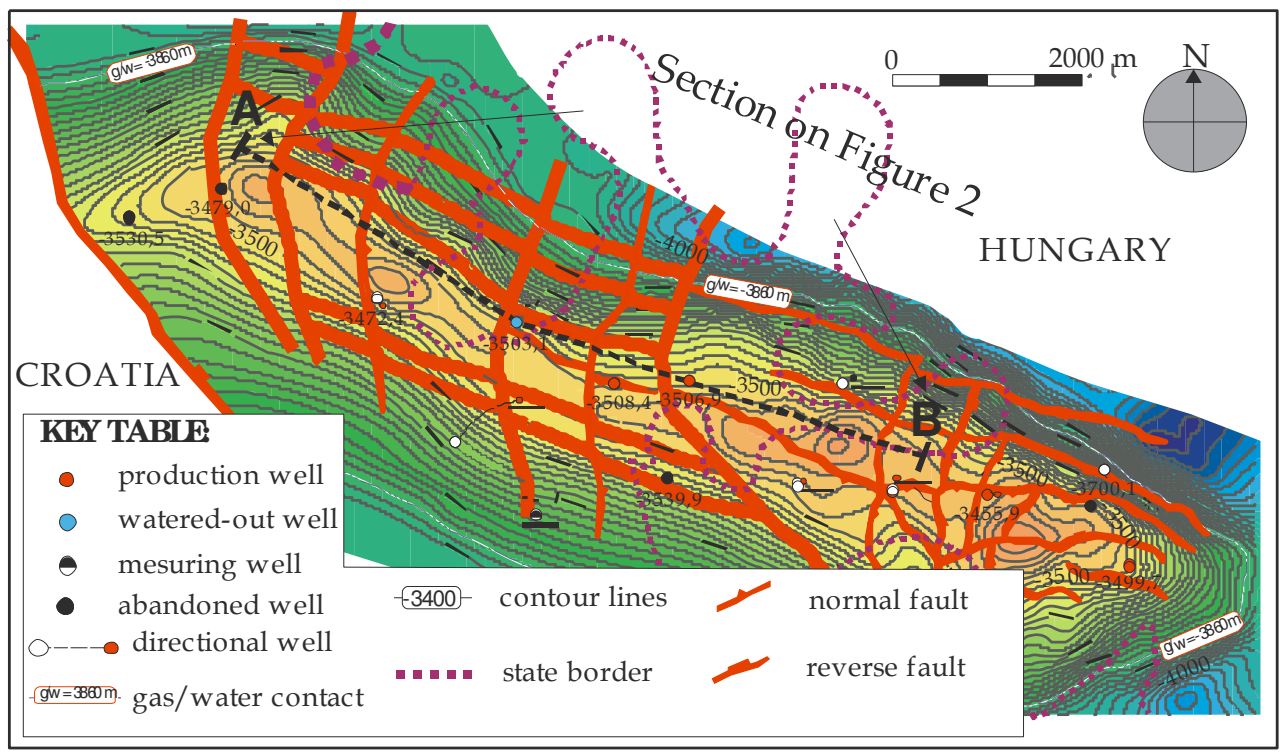

Fig. 6. Structural map of Badenian top (from Malvić, 2006; modified after Gaćeša, S., Futivić, I., Gyorgy, F. and Horvath, Z. (2001): Barcs Nyugat - Stari Gradac field study. INA-Naftaplin \& MOL KTD, company archive, INA-Naftaplin, Zagreb)

\subsubsection{Deposition mechanism during Late Pannonian and Early Pontian ( $^{\text {nd }}$ transtension or $2^{\text {nd }}$ megacycle)}

In the Late Pannonian and Early Pontian (9.3-5.6 Ma), CPBS depressions were lacustric parts of the Pannonian Basin System, divided in partially independent elongated areas of brackish environments (e.g. Sava Depression had width of $25 \mathrm{~km}$ and a length of $100 \mathrm{~km}$ ). In this period PBS was an open lake system, composed of several connected basins with active inflows and outflows (rivers) that have been described in detail by Bérczi et al. (1988). The chemical composition of water was determined by continuous inflows of fresh water from rivers, what resulted in the development of slightly brackish and eventually fresh lake environment.

Croatian depressions had a very complex palaeorelief, especially the Sava and Drava Depressions, which represented typical tectonic grabens, with deep, elongated central part, and marginally uplifted parts of shallow water or continental palaeorelief (Fig. 7). Consequently, the largest thickness and lithofacies types had been described for central depression parts, simply because there was enough large accommodation space for the most sediment quantity. Mechanism of sediments transportation included turbidite flows. The major part of the siliciclastic material originates from one regional source (Eastern Alps). The last slope before CPBS, which contained detrital material that was accumulated with varying intensity, was probably located into the Mura depression (north of Varaždin). From this point, due to tectonic events, sediment was relocated and transported to the Drava, Sava and Slavonia-Srijem depressions. Such relocation was highly subdued by depression's palaeorelief. In the central parts depressions were surrounded by basement highs (somewhere even above sea-level), where water depths was mostly deeper than $200 \mathrm{~m}$. The 
erosion level of turbidites had been the strongest just in these central, deeper channels. But, such central parts are also place of large and thick sandstone bodies. However, it is necessary to outline that in the central part of PBS (e.g. Békés Basin in Hungary) the depositional mechanism had been partially different then on the margins of PBS. For example, Juhász and Magyar (1992) proved two main delta systems were dominated, which were Gilber-type deep water deltas. The sediment accumulation is reconstructed from two directions, from NW and NE, which encountered in Békés Basin.

But, observing again CPBS turbiditic flows (or currents) had been determined by positions of Medvednica, Kalnik and Moslavačka gora Mts., i.e. location of the Mura Depression at very NW margin of CPBS. This depression was the first regional depositional centre for turbidites. As it was relatively shallow, the large quantities of clastics had been accumulated on eastern margin (tectonic ramp) of the Mura Depression, and later tectonically moved on the S/SE. Southern from uplifted palaeomountains re-activated turbidites transported material toward south in the Sava and northern in the Drava and Slavonia-Srijem Depressions. The strongest indicator of turbidite direction is the geometry of the sandstone bodies. The sandy detritus was transported into the depression exclusively by turbidites, and the primary flow direction had an arching (curved) shape from the NW, and later N, and somewhere even NE (influenced by palaeorelief). During a period of inactivity, permanent basin sedimentation resulted in deposition of the finest detritus throughout the entire CPBS. Structurally, main channels carried along the main part of the sandy material, while the minor part was deposited in the inter-channel areas. In addition, the channel locations were changed through space and time, continually migrating, thereby defining the inter-channel area pattern.

In such transport directions the crucial role had Moslavačka gora Mt. (Fig. 7) that separated Sava and Drava Depressions, and regional dipping of the depressions toward SE and E. Moreover it is proven that turbidites in the Sava Depression had been transported through two main channels - northern and southern, and during the Early Pontian deposition in the NW part of the Sava Depression was locally inclined firstly toward S (Vrbanac et al., 2010) and locally even toward the SW (Hernitz \& Jurak, 1973). This was likely the result of the uplifting of Moslavčka gora Mt., stronger subsidence of the Donja Jelenska and Ilova sags in the NE and existence of Martinska Ves horst in the SW margin of the Sava Depression. Also, this depression had been also $S$ margin of the CPBS, which was closed by mostly underwater palaeorelief located between the Psunj and Prosara Mts. (Blašković, 1982), what also was pinchout zone of the turbidites.

The Drava Depression had more irregular shape due to SW "extension" of the rhomboidal Bjelovar Subdepression (Fig. 7). However sedimentation was similar to the Sava Depression. It means monotonous alteration of sandstones and marls in the central part, while the Bjelovar Subdepression as relatively closed basin of moderate palaeorelief included significantly more hemipelagic marls, especially in Late Pannonian. The final forming of the Drava Depression was took part during Pliocene and Quaternary when northern margin of the Bjelovar Subdepression, the Bilogora Mountain was uplifted (2-3 Ma ago) and separated these depositional areas in practically different depressions.

Reconstruction of the palaeorelief can indicate the palaeodepth of the CPBS Neogene lakes. The most reliable indicator of water depth and the depositional environment are the remains of animals and plants (biotop) that characterise particular environments. Unfortunately, the Upper Pannonian sediments contain very few fossils. However, some macrofossils, microfossils and palinological analysis showed at the point at which the 
transition from brackish to fresh water occurred just in Late Pannonian. Some other indicates the presence of shallow water in that period (e.g. Pletikapić, 1965, Lučić et al., 1995). Relatively rare samples of sporomorphs would indicate that land was relatively far, but the presence of kerogen type III (terrestrial) supports conclusion (Lučić et al., 1995) that the shore was close.

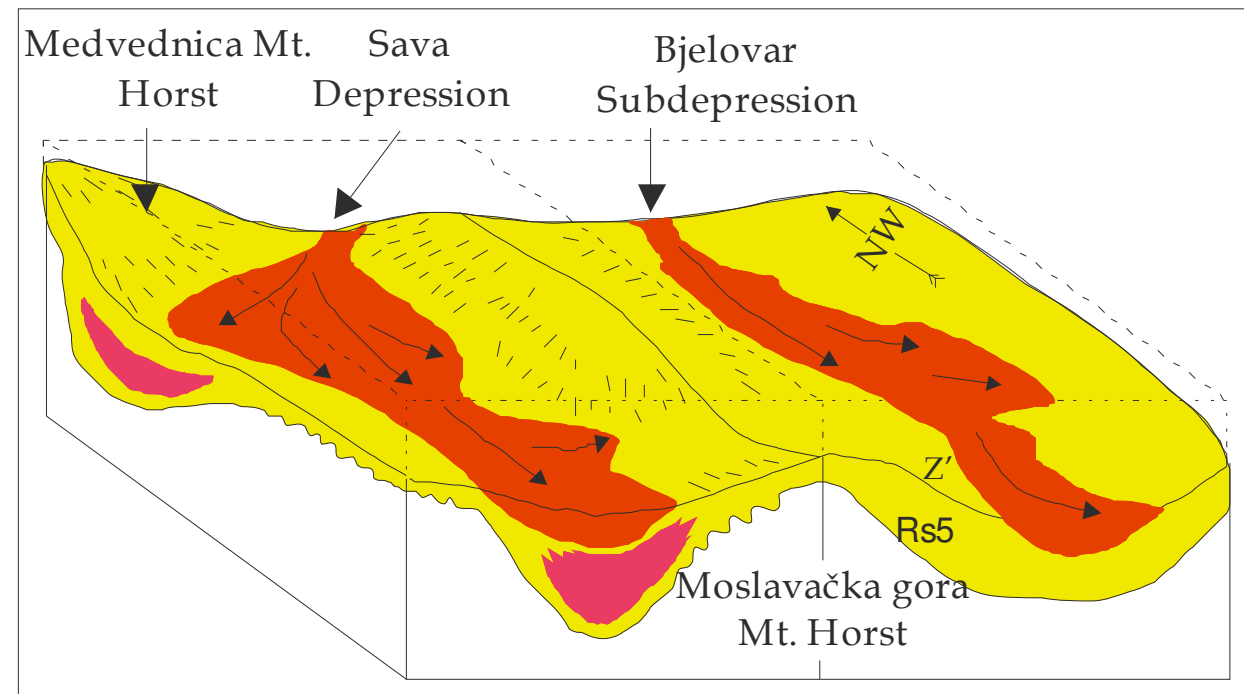

\section{Legend:}

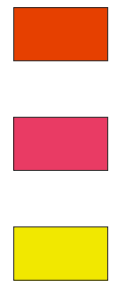

Depositional body of Okoli Sandstones (Early Pontian)

Depositional body of Iva Sandstones (Late Pannonian)

Association of massive marl of Ivanić-Grad Formation

(Zagreb Member and Lipovec Marl)

Z' electro-log marker (Late Pannonian/Early Pontian)

Rs5 electro-log marker (Early/Late Pannonian)

Fig. 7. Schematic palaeographic situation on the border between Sava and Drava Depressions at the end of Late Pannonian (from Vrbanac et al., 2010)

Regarding the relatively narrow depositional depressions it is not clear where the beaches and shoals could be located and where the transported material was eroded only from the close land. However, if marls are defined as sediments of swamps and lagoons, but which do not include in present cores any characteristics that indicate the presence of close land 
areas, it can hardly be accept. Even if they are reworked some fossils could be found in collection of numerous well cores.

Also it is illogical assume that throughout the entire Late Pannonian (which was about $2 \mathrm{Ma}$ long), in a tectonically active depressions, shallow marsh environment existed all the time with constant water level. Indeed, this would means that no parts of the shallow-water (marsh, lagoons) were exposed to the air, due to continuously deepening and compensating sedimentation rate. Also, there are no evidences for delta activities and erosion of on-shore and near-shore material (like mud and marl) from exposed land. All these facts (assumptions of far land or near shore) can be explained by such mechanism that allowed clastic materials could be derives from distant near-shore environment, and then delivered by turbidity currents to the deeper parts of the basins, also several times reworked (like also skeletal and plant remains) and redeposited.

So, today for CPBS is accepted deeply water (more than $200 \mathrm{~m}$ in the deepest parts; Fig. 8), turbidite mechanism as the main source of Upper Miocene sandstones in CPBS. Also complete sequence of massive, hemipelagic marls deposited over the basin plain has been described both in the marginal and central parts of depressions, indicating on calm basin environment. Such lake environment can explain all of the rapid changes in lithologies (especially vertically) and the nearly identical depositional conditions that were observed over a geological ages of Late Pannonian and Early Pontian.

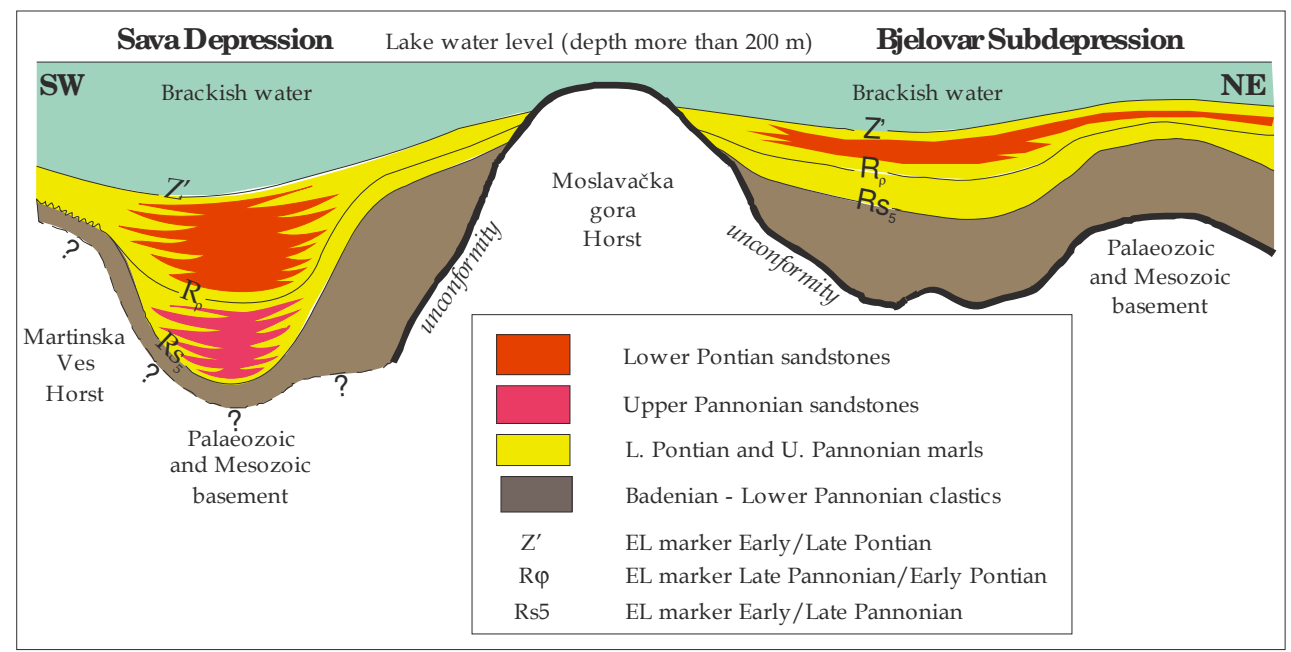

Fig. 8. Schematic palaeographic reconstruction in the beginning of Late Pontian at margin between the Sava and Drava Depressions (modified after Vrbanac et al., 2010)

Sedimentary, mineralogical and petrographic characteristics of the Upper Pannonian and Lower Pontian sediments in CPBS are very similar. The majority of the detritus originates from the Alpine mineral association (Šćavničar, 1979). Transport from Alps has taken a very long time, and the material was re-deposited several times. This explains why the sandstones are mostly medium- to fine-grained, with relatively rounded grains. Conversely, the influence of local horst as a source of detritus has been limited as they probably were under water at that time. According to large distance from Eastern Alps it can be assumed 
that margins of CPBS (especially eastern Drava and Slavonia-Srijem Depression) were not only filled by turbidites, but also with clastics originated from much closer palaeomountains, like Mecsek in southern Hungary. However, it is still not undoubtedly proven.

\subsubsection{Main facies associations in Upper Miocene turbiditic environments}

Turbiditic clastic environments are the most complex depositional facies through entire Neogene in CPBS, also characterised with the largest thickness and extension of reservoir lithofacies. It is why here will be described such lithofacies, using the most characteristics basin facies association for period from Upper Pannonian to Lower Pontian. There can be distinguished several facies association in all depression. Recently it was very detailed described for the Sava Depression and Bjelovar Subdepression (Vrbanac et al., 2010), but can be almost in the same way accepted for entire CPBS.

The facies with the main reservoir potential is turbidite channel fill facies association consists of thick-bedded sandstone facies and thin-bedded sandstone facies. The channel axis is usually characterised by thick sandstone beds with rare marl layers. The number of marl layers is greater in the channel margins, while the basin plain sandstones are thinner and contain more fine-grained sediments.

Usually this association in the lower part is composed of thick bedded sandstones, which strongly eroded marls in bottom of turbiditic flow. In fact, the energy of currents was strongest inside the channel, which resulted in strong bottom erosion. Therefore, the missing marl that could be deposited in the previous calm period due to energy of turbidite currents was probably eroded, what is the result of activity in channel axis where the current was the strongest. Such feature describes channels as depositional (Hamilton, 1967) and erosional (Laughton, 1968) environments in which the main current mass was transported.

Moreover, channel facies association is composed of thin bedded sandstones in the upper parts (when the channel began to be less active and eventually inactive). If the channel is abandoned rapidly, there is no observed upward fining and thinning sequences what is often event in many CPBS hydrocarbon fields. Then SP log is characterised by a cylindrical shape (Pirson, 1970). Erosion of channel bottom was strongest in the central parts of the channels and weaker in the margins, which indicates that the positions of the channel in distributary system can be determined based on the number of altered marl layers. Specifically, the positions can be deduced based on the direction of the main current during different periods. In the proximal and bottom parts of the current the particle concentration was highest, while the majority of suspended detritus was deposited in distal areas due to the decreasing energy. This resulted in the maximum sandstone thicknesses being developed in channels that were formed in according to basin morphology and synsedimentary tectonics.

Turbidite overbank-levee facies association is composed of facies of laminated sandstones, siltstones and marls in the lower part and facies of sandstone layers in the upper part. Sediments of this facies association were deposited outside the distributary channels, where the turbidity currents were significantly weaker, which created overbank-levee, fringe and channel bank deposits. These characteristics resulted in the erosional effects being smaller than in the channel facies. As a result, amalgamations are very rare and the thickness of eroded marls is probably not higher than several to several dozen centimetres. However, the 
total thickness of the sandstone body in this association can be more than $30 \mathrm{~m}$ and shows upward thickening. This association is characteristic at the marginal parts of channels and the channel's banks. This indicates that the distribution was not restricted to the channels, but also occurred in the wider channel area, which resulted in thick sandstones occasionally being deposited in bank (levee) areas.

Lateral or distal turbidite facies association consists of a monotonous alternation of very thin (laminated), thin and medium thick sandstone beds passing into siltstones and marls. In this association, erosion on the bedding plane is almost completely absent. The sublayers of marls and sandstones are so thin that they are beyond the resolution of well-log curves. Sediments of this association are recognized in distal areas, where the maximal range of turbidites occurred. Moreover, such sediments are discovered on morphologically uplifted parts between channels or further away from the channels for great distances. Consequently, the portion of siltstones and marls in the facies is increased and the portion of marly sandstones and sandstones is decreased. The total thickness of this association can reach several dozens of meters, and can cover several hundreds of meters laterally. This distal turbidite association can be compared with classical turbidite sequences that are deposited (Walker, 1978) at the end of the distal part of a lower fan in the basin plain, which is the area in which the maximal extensions of the turbidity current exist. Such distal turbidite associations can also be found on the banks of the upper fan (Walker, 1978). Generally, they are the result of the deposition of sandy and fine-grained detritus in the marginal, transitional parts of the basin (or in CPBS areas between strikeslip depressions), between the main current flow and morphologically uplifted areas. These results indicate that deposition was active in areas where turbidity current is still active, but only from a thin portion of the current cloud. This part of current is characterised with low energy, which resulted in only small quantities of sandy detritus being transported.

Massive marls facies association is primarily represented by massive marl facies with rare intercalations of thin siltstone or sandstone laminae. Sediments in this association are continuously deposited in marginal areas or areas outside the range of turbidites. However, deposition of these marls was also active in the central parts of the depressions during periods of calm basin sedimentation in which there were no turbidite activities. This association can be compared to hemipelagic sediments of open seas.

\subsection{Hydrocarbon reserves and reservoir characteristics in CPBS}

Approximately $104 \times 10^{6} \mathrm{~m}^{3}$ of oil from 39 fields, $6.93 \times 10^{6} \mathrm{~m}^{3}$ of condensate (11 fields) and $64.92 \times 10^{9} \mathrm{~m}^{3}$ of gas (52 fields) were recovered in the Croatian part of the Pannonian basin during 63 years of exploitation. Detail calculation is performed for period 1941-2004 in Velić et al. (2010). The total production peak was attained in 1980-1989, when exploration resulted in discoveries of 12 oil (Fig. 9) and 20 gas (Fig. 10) fields. Generally 30 years (1960-1989) can be described as a highly successful exploration period (Fig. 9 and Fig. 10).

The total (geological) reserves are about $740 \times 10^{6} \mathrm{~m}^{3}$ of equivalent oil, with recoverable reserves of $112 \times 10^{6} \mathrm{~m}^{3}$ of oil, $10.74 \times 10^{6} \mathrm{~m}^{3}$ of condensate and $100.67 \times 10^{9} \mathrm{~m}^{3}$ of gas (Belošić, 2003; Velić et al., 2008). Up to 2004 a total of $175.89 \times 10^{6} \mathrm{~m}^{3}$ of equivalent oil had been recovered from Croatian fields, including $104.05 \times 10^{6} \mathrm{~m}^{3}$ of oil from 39 fields, $6.93 \times 10^{6}$ $\mathrm{m}^{3}$ of condensate from 11 fields and $64.91 \times 10^{9} \mathrm{~m}^{3}$ of gas from 52 fields (Velić et al., 2010; Fig. 11). 


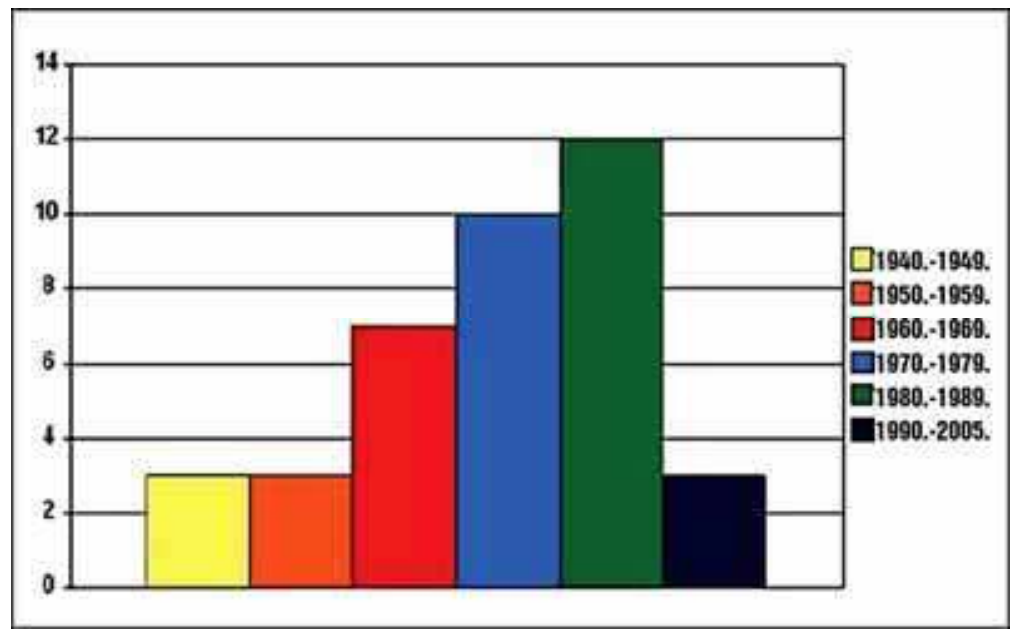

Fig. 9. Number of discovered oil fields during 1945-2005 (from Velić et al., 2010)

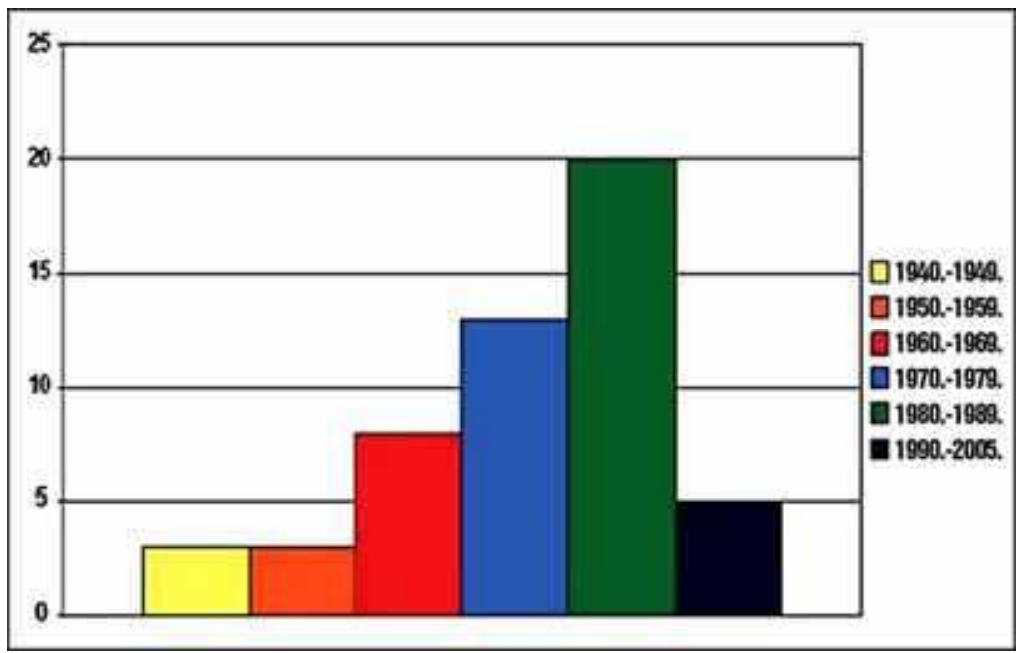

Fig. 10. Number of discovered gas fields during 1945-2005 (from Velić et al., 2010)

Production is decreased after 1989 caused by depletion (maturation) of older fields, and substantial decrease in exploration activities. Dependence between these two factors it is not favourable condition, because reserves decreasing can be only ceased by discovering of new proven reserves as result of new exploration drilling. But total recovery of proven reserves is continuously increasing due to application of additional method for improving recovery. The most applied secondary recovery method for many fields is water injection. However, the fields of all sizes are often revitalized with mechanisms of artificial (gas) lift. Also, it is proven, especially in the largest oil fields, that sandstone reservoirs of Pannonian and Pontian age have the most favourable values of petrophysical properties and consequently the highest recoveries and the longest production period (Velić et al., 2002). 


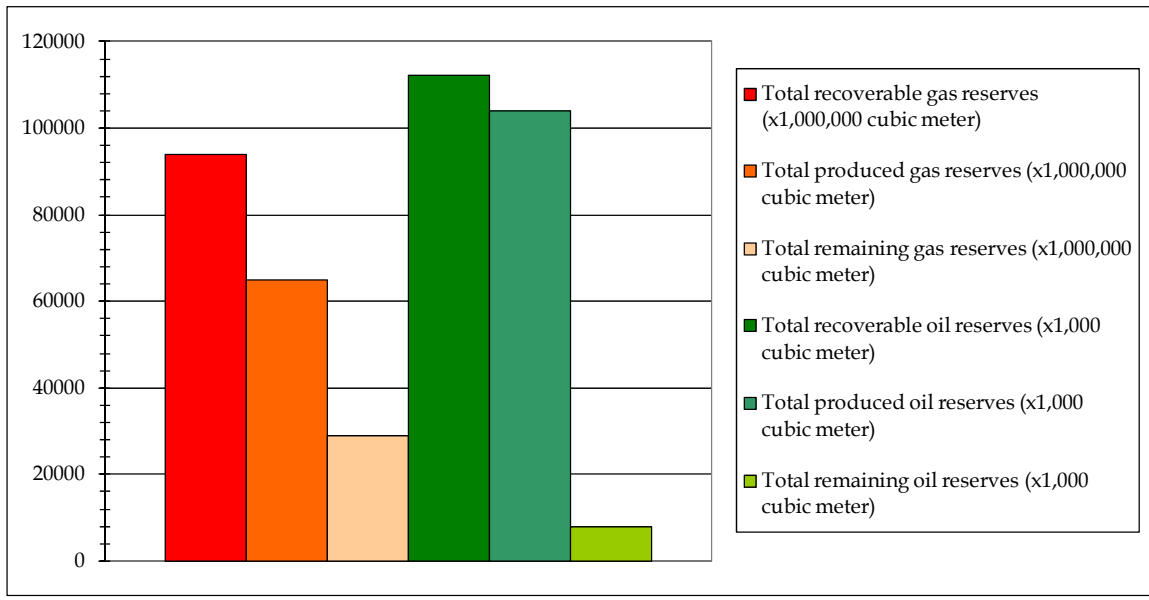

Fig. 11. Total hydrocarbon recoverable, produced and remaining reserves in CPBS (from Velić et al., 2010)

\subsubsection{Hydrocarbon reserves in numbers}

Regarding reserves, there are many sources and estimations. But, recently there are published two estimations in internationally reliable source (Dobrova et al., 2003; Velić et al., 2010) for CPBS. Lower estimation originated from 2010 (Velić et al., 2010), and higher from 2003 (Dobrova et al., 2003). Also, the complete deterministical calculation procedure for reserve estimation in CPBS through geological categories that define petroleum system is presented in Malvić (2003) and later upgraded in Malvić \& Rusan (2009).

According to earlier estimation (Dobrova et al.; 2003) Croatia is ranked in third place according to the remaining recoverable liquid reserves in the central and eastern European states regarding reserves at the end of 2002 (Romania first, 39\%; Ukraine second, 25\%; and Croatia, Austria and Belarus third, 6\%). But later Velić et al. (2010) included newer production data from CPBS are stated that recoverable oil reserves are lower $-112.06 \times 10^{6} \mathrm{~m}^{3}$ of oil (+ $10.73 \times 10^{6} \mathrm{~m}^{3}$ of condensates), versus $141.18 \times 10^{6} \mathrm{~m}^{3}$ of oil in Dobrova et al. (2003). For gas ratio is $100.67 \times 10^{6} \mathrm{~m}^{3}$ (Velić et al., 2010) vs. $108.11 \times 10^{9} \mathrm{~m}^{3}$ (Dobrova et al., 2003). But decreasing published for remaining reserves is more dramatic and for oil it is $8.01 \times 10^{6} \mathrm{~m}^{3}+$ $3.80 \times 10^{6} \mathrm{~m}^{3}$ of condensate (Velić et al., 2010) vs. $31.48 \times 10^{6} \mathrm{~m}^{3}$ (Dobrova et al., 2003), and for gas $35.76 \times 10^{9} \mathrm{~m}^{3}$ (Velić et al., 2010) vs. $81.95 \times 10^{9} \mathrm{~m}^{3}$ (Dobrova et al., 2003).

In any case, significant remaining hydrocarbons could be recovered from reservoirs with proven reserves in CPBS. It is sure that there are some subtle, potentially medium or small reservoirs of about 200,000 $\mathrm{m}^{3}$ recoverable oil equivalent (Malvić, 2003; Malvić \& Rusan, 2009), where can be located remaining reserves (Fig. 11). There are two stratigraphic plays as targets, logically based on two previously described depositional environments, which could be considered for future explorations. The first ones are smaller structures in Badenian sediments. Reservoirs of such age are generally coarse-grained sediments, deposited in smaller (generally up to $5 \mathrm{~km}$ in longer axis) strike-slip depressions. The largest such fields are already discovered, but there is for sure smaller structures of such type that were not recognized earlier on regional seismic sections, subsurface geological maps or include large uncertainty about possible accumulated hydrocarbons (e.g. in Malvić, 2003). 
The second ones targets are Upper Miocene sandstones, where hydrocarbon recovery can be increased by producing from marginal, thin or marly (inter-channel) sandstone layers. Also, the largest sandstone reservoirs in CPBS are very probable accompanied with several satellite or smaller reservoirs as separate hydrodynamic units.

\subsubsection{Hydrocarbon reservoirs characteristics}

Hydrocarbon reservoirs absolute depths in CPBS range approx. from 400 to $4000 \mathrm{~m}$. Initial reservoir pressure is hydrostatic or higher. Average geothermal gradient is about $4.5^{\circ} \mathrm{C} / 100$ $\mathrm{m}$, but locally can vary $30-40 \%$. Gas and condensate reservoirs are always over-pressured, with average gradient $0.16 \mathrm{bars} / \mathrm{m}$. Temperature of reservoirs are sometimes high (180$\left.220^{\circ} \mathrm{C}\right)$ with large part of non-hydrocarbon gases $\mathrm{CO}_{2}(10-25 \%), \mathrm{H}_{2} \mathrm{~S}(60-200 \mathrm{ppm})$ and mercury.

The oldest reservoir rocks are proven in the Šumećani (Palaeozoic schists and granites), Bunjani (Palaeozoic granites and gneisses), Molve, Kalinovac and Stari Gradac-Barcs Nyugat Fields (highly tectonized Palaeozoic schists and quartzites of Permian and Triassic systems). On the east, the oldest reservoirs are discovered in Ilača, Privlaka and Đeletovci Fields (pre-Cenozoic). There are significant reserves found in Mesozoic (Triassic) dolomites in Molve, Kalinovac and Stari Gradac Fields.

The most important Badenian reservoirs in CPBS are located in the Sava and Drava Depressions. In the eastern part of Drava Depression the largest is Beničanci Field, from where is recoverable about $18 \times 10^{6} \mathrm{~m}^{3}$ of oil. Smaller, but economical, reservoirs of that age are located in surrounding Obod, Kučanci-Kapelna, Bokšić-Klokočevci and Števkovica Fields. Badenian reservoirs are proven also in Mura Depression (Legrad Field), Sava Depression (Vezišće, Stružec and Kloštar Fields) and elsewhere. Generally, the most hydrocarbons from reservoirs of $1^{\text {st }}$ megacycle are recovered from eight fields: Beničanci, Molve, Kalinovac, Žutica, Stružec, Ivanić, Šandrovac and Bokšić.

The largest hydrocarbon reserves (recovered and remained) in CPBS belongs to sandstones of Upper Pannonian and Lower Pontian. These reservoirs are deposited during 2nd megacycle, and the best properties are proven in central parts of depressions for thick and lithologically clean, medium and fine-grained sandstones. Average primary (inter-granular) porosity is often higher than $20 \%$ and permeability is about $60 \times 10^{-3} \mu \mathrm{m}^{2}$. The largest sandstone reservoirs are discovered in the Sava Depression on Stružec Field (16x106

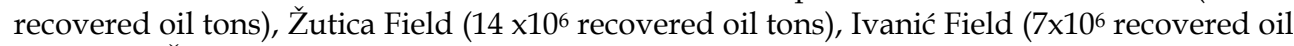
tons) and Šandrovac Field (6.5 x106 recovered oil tons) in the Drava Depression. Three largest fields in CPBS (Beničanci, Molve and Kalinovac) contain hydrocarbon reserves of approx. $200 \times 10^{6}$ tons of oil equivalent, and are classified in 1000 the world's largest hydrocarbon fields (Velić, 2007). The main gas reservoirs (also rich in condensate) are Molve, Kalinovac and Stari Gradac-Barcs Nyugat in the western Drava Depression, with $70 \%$ gas reserves in CPBS.

\section{Conclusion}

Neogene and Quaternary tectonics in the Croatian basin is very complex, due to two phases of transtension (Badenian and Late Pannonian-Early Pontian) and two of transpression (Sarmatian-Early Pannonian and Late Pontian-recent). Transtensions were periods of main sediment accumulation and transpression of uplifting and structural forming. Consequently, there are lithological heterogeneities laterally and vertically as well as 
occurrence of numerous fault zones. Such faults separate regional tectonic blocks and very often bordering hydrocarbon field structures, acting as partial or complete seals. Pressure and production anomalies can be a useful indicator of fault sealing, observing at wells located on opposite blocks.

Middle Miocene was period when a numerous strike-slip negative flowers had been formed inside regional depressions of CPBS. Such places were depositional centres of alluvial fans, where coarse-grained sediments from local sources of clastics, with good reservoir properties, were deposited. Moreover, numerous intra-reservoir micro-zones of secondary porosity are present in basement of such reservoirs owing to the complex Middle Miocene transtensional tectonic reflected in Palaeozoic and Mesozoic basement rocks. Results are single hydrodynamic units of heterogeneous reservoirs of Palaeozoic, Mesozoic and Middle Miocene (rarely Lower Miocene), where unconformities play the most important role. Stratigraphycally, such unconformities are loci for lengthy exposure at the surface before Badenian transgression. Heterogeneity and the ages of reservoir rocks, which span several geological erathems, strongly emphasise diagenesis as a highly important process in Mesozoic basement rocks. Rocks of these sediments today represent the $2^{\text {nd }}$ reservoir unit according with importance of remaining and potential hydrocarbon reserves. The modern resolution of petroleum exploration techniques today make possible to detect also smaller, but economically interesting reservoirs as the new discoveries.

Upper Miocene encompasses turbiditic depositional mechanism strongly characterised by single source area located at western margins of PBS (Eastern Alps). Reservoir rocks are sandstones, which reached the highest thicknesses in central parts of CPBS depressions. The major influence on sandstone reservoir quality had increasing of silty and marly components in marginal depression parts and decreasing of thickness. Also, mechanical diagenesis, as a process of compaction, caused a decrease in porosity for depth difference more than 400 meters in the same lithostratigraphic member (Malvić et al., 2005). It happened especially in deeper parts, but has minor influence compared with increasing of silty and marly components in marginal parts. The third process, also of minor influence, had been chemical diagenesis including several processes caused by dissolved ions, $\mathrm{pH}$ value, pressure and temperature. in any case, sandstone reservoirs contain the largest proven hydrocarbon reserves. Also, there are projected the highest possible (undiscovered) quantities of oil and gas, but for difference of Badenian coarse-grained reservoirs, in sandstones such reserves would be located close to existing fields in the so called subtle traps, i.e. as satellite reservoirs. Such targets were not explored in the past, due to smaller areal extension and often not so favourable lithological composition (transitional lithofacies). But, as total recovery increase thanks to new technologies, such reservoirs start to be important hydrocarbon source.

Total remaining hydrocarbon potential in CPBS makes this area interesting for future exploration. Remaining reserves are probably at least $8 \times 10^{6} \mathrm{~m}^{3}$ of oil, $3.80 \times 10^{6} \mathrm{~m}^{3}$ of condensate and $36 \times 10^{9} \mathrm{~m}^{3}$ of gas (Velić et al., 2010). Middle Miocene sediments probably hide some undiscovered smaller structures on depressions margins, and in Upper Miocene subtle traps are probably remained as satellite structures around existing larger sandstone reservoirs. The majority of remaining hydrocarbons is assumed in Upper Miocene sandstones.

The strike-slip tectonics played crucial role in shaping CPBS with contemporary structures and hydrocarbon fields. These fault systems play two important roles. In transtensional phases they formed negative flower structures where sediments had been accumulated 
(both in Middle and Upper Miocene). On contrary, in transpressional phases they were changed in positive flower structures, especially in $2^{\text {nd }}$ transpressional period, forming traps for hydrocarbon accumulations as well as migration pathways (e.g. in Malvić, 2003 or Velić, 2007). The main fault displacement happened along the bordering strike-slip faults, between which structure had been formed.

Also, tectonic and sedimentation in CPBS, which occurred through 2 transtensional and 2 transpressional phase, can be analysis additionally through three depositional megacycles. Properties of such megacycles can be followed on seismic sections, well cores, logs, and outcrops on surface, even in large scale (Blašković et al., 1984). The $1^{\text {st }}$ megacycle corresponds with $1^{\text {st }}$ transtensional phase and mostly included coarse-grained reservoir sediments in older, and pelites (often source rocks) in younger part. The $2^{\text {nd }}$ megacycle corresponds to $2^{\text {nd }}$ transtensional phase of Late Miocene, and included the sandstones that are the main reservoirs regarding volumes and recoverable hydrocarbons in CPBS. These rocks resulted from periodical, strong turbiditic currents that generally moved from NW/N toward SE/S, and which direction had been strongly determined by marginal depression's faults, local strike-slip structures and uplifted, subaqueous palaeoreliefs remained from $1^{\text {st }}$ transtensional phase. The $3^{\text {rd }}$ megacycles is connected with $2^{\text {nd }}$ transpressional phase, which took place the most of time in continental environment. This phase has importance for final structural evolution of CPBS but also in the last decade some researching results opened possibilities for economical biogenic methane accumulation in Pliocene and Lower Quaternary sediments. Some projections indicate that such accumulations are often located above existing reservoirs as represent mixture of thermogenic and biogenic gases.

Croatian part of Pannonian Basin System is large and well geologically described Neogene and Quaternary regional basin system. Many analyses offered enough data and results for describing geological evolution of this area and transfer methods and conclusion in other similar geological provinces. This basin system is also well known area of numerous hydrocarbon reservoirs, where some of them are classified as very large in world scale. Although this province is today considered as mature petroleum basin, there is still enough remaining reserves for production in next several decades, what is here described numerically for CPBS. But, technological improvements also make possible increasing of recovery from discovered reservoirs as well as discovering some smaller and subtle traps. Presented analysis for CPBS makes easier to understand in which stratigraphical units and tectonical environments such traps can be found in CPBS.

\section{Acknowledgment}

This work represents part of a multidisciplinary research carried out in 2010 and 2011 within the larger project entitled "Stratigraphical and geomathematical research of petroleum geological systems in Croatia" (project no. 195-1951293-0237), financed by the Ministry of Science, Education and Sports of the Republic of Croatia.

\section{References}

Barić, G., Mesić, I., Jungwirth, M. \& Španić, D. 1991. Gas and gas condensate-field in the north-west of the Drava depression, Yugoslavia, In: Generation, Accumulation, and Production of Europe's Hydrocarbons. A.M. Spencer (Ed.), Special Publication of the 
European Association of Petroleum Geoscientists, 508 p., Oxford University Press , No. 1, pp. 323-339, ISBN-10: 0198542828, Oxford, UK.

Barić, G., Mesić, I. \& Jungwirth, M. (1998). Petroleum geochemistry of the deep part of the Drava Depression, Croatia. Organic Geochemistry, Vol. 29, (December 1998 on-line), No. 1-3, pp. 571-582, ISSN 0146-6380.

Belošić, Ž. (2003). Istraživanje i proizvodnja nafte i plina [Exploration and production of oil and gas]. Proceedings of $2^{\text {nd }}$ International scientific-professional congress on petroleum industry, Zadar, September-October 2003.

Bérczi I., Hamor G., Jambor A. \& Szentgyörgyi K. (1988). Neogene Sedimentation in Hungary. In: The Pannonian Basin, L.H. Royden and F. Horváth (Eds.), AAPG Memoir, Vol. 45, pp. 57-67, ISBN 0891813225, Tulsa, USA.

Blašković I. (1982). The Neogene of the Ilova River depression (Northern Croatia). Jugosl. akad. znan. i umjetnosti, Acta geologica (Prirodoslovna istraživanja 46), Vol. 12, No. 2, pp. 23-67, ISSN 0448-0155.

Blašković, I., Tišljar, J., Dragičević, I. \& Velić, J. (1984). Razvoj sedimentacijskih okoliša miocenskih naslaga na zapadnim obroncima Psunja (sjeverna Hrvatska) [Application Evolution of depositional environments of Miocene sediments on western hills of Psunj Mt. (northern Croatia)] (in Croatian). Geol. vjesnik, Vol. 37, pp. 11-32, ISSN 0016-7924.

Ćorić, S., Pavelić, D., Rögl, F., Mandić, O., Vrabac, S., Avanić, R., Jerković, L. \& Vranjković, A. (2009). Revised Middle Miocene datum for initial marine flooding of North Croatian Basins (Pannonian Basin System, Central Paratethys) The Pannonian Basin System (PBS) originated during the Early Miocene as a result of extensional processes between the Alpine-Carp. Geologia Croatica, Vol. 62, No. 1, pp. 31-34, ISSN 1330-030X.

Dobrova, H., Kolly, E. \& Schmitz, U. (2003). E\&P Ventures in the Eastern-Central Europe Transformation States after 1989 - a Review of Expectations and Results. Oil Gas European Magazine, Vol. 30, No. 4., pp. 172-182, ISSN 0342-5622.

Hamilton E.L. (1967). Marine geology of abyssal plains in the Gulf of Alaska. Journal of Geophysical Research, Vol. 72, No. 16, pp. 4189-4213, ISSN 0148-0227.

Haq, B. U. \& Eysinga, F. W. B. (Eds.) (1998). Geological Time Table, Fifth Edition (Wall Chart). ISBN 0444828656, Elsevier Science, Amsterdam, The Netherlands.

Hernitz Z. \& Jurak V. (1973). Primjena paleostrukturne i statističke analize naslaga mlađeg tercijara u području Ivanić-Grada (sjeverna Hrvatska) [Application of Palaeostructural Analysis of Late Tertiary sediments in the area of Ivanić-Grad (northern Croatia)] (in Croatian). Nafta, Vol. 24, No. 7-8, pp. 343-367, ISSN 0027$755 \mathrm{X}$

Juhász, G. \& Magyar, I. (1992): Review and correlation of the Late Neogene (Pannonian s.l.) lithofacies and mollusc biofacies in the Great Plain, eastern Hungary. Foldtani Kozlony, Vol. 122, No. 2-4, pp. 167-194, ISSN 0015-542X.

Kovač, M., Barath, I. \& Nagymarosy, A. (1997). The Miocene collapse of the AlpineCarpathian-Pannonian junction - an overview. Acta Geol. Hungarica, Vol. 40, No. 3, pp. 241-264, ISSN 1788-2281.

Laughton A.S. (1968). New evidence of erosion on the deep ocean floor. Deep Sea Research (continued as Deep Sea research and Oceanographic Abstracts), Vol. 15, No. 1, pp. 21-29, ISSN 0146-6291. 
Lučić D., Krizmanić K. \& Dalić N. (1995). Lithofacies and Sequence Stratigraphy of Upper Miocene Siliciclastic Deposits in Okoli Region (Sava Depression, Croatia). Abstract book of the $1^{\text {st }}$ Croatian Geological Congress, ISBN 953-96520-4-9, Opatija, October 1995.

Lučić, D., Saftić, B., Krizmanić, K., Prelogović, E., Britvić, V., Mesić, I. \& Tadej, J. (2001). The neogene evolution and hydrocarbon potential of the Pannonian Basin in Croatia. Marine and petroleum Geology, Vol. 18, No. 1, pp. 133-147, ISSN 0264-8172.

Malvić, T. (1998). Strukturni i tektonski odnosi, te značajke ugljikovodika širega područja naftnoga polja Galovac-Pavljani [Structural and Tectonic Relations in the Wider Area of Galovac-Pavljani Oil Field]. MSc. thesis, Faculty of Mining, Geology and Petroleum Engineering, University of Zagreb.

Malvić, T. (2003). Naftnogeološki odnosi $i$ vjerojatnost pronalaska novih zaliha ugljikovodika u bjelovarskoj uleknini [Oil-Geological Relations and Probability of Discovering New Hydrocarbon Reserves in the Bjelovar Sag]. PhD. thesis, Faculty of Mining, Geology and Petroleum Engineering, University of Zagreb.

Malvić, T. (2006). Middle Miocene Depositional Model in the Drava Depression Described by Geostatistical Porosity and Thickness Maps (Case study: Stari Gradac-Barcs Nyugat Field). Rudarsko-geološko-naftni zbornik, Vol. 18, pp. 63-70, ISSN 0353-4529.

Malvić, T., Velić, J. \& Peh, Z. (2005): Qualitative-Quantitative Analyses of the influence of Depth and lithological Composition on Lower Pontian Sandstone Porosity in the Central Part of Bjelovar Sag (Croatia). Geologia Croatica, Vol. 58, No. 1, pp. 73-85, ISSN 1330-030X.

Malvić, T. \& Rusan, I. (2009). Investment Risk Assessment of Potential Hydrocarbon Discoveries in a Mature Basin. Oil Gas European Magazine, Vol. 35, No. 2, pp. 67-72, ISSN 0342-5622.

Malvić, T. \& Velić, J. (2010). Relation between Effective Thickness, Gas Production and Porosity in Heterogeneous Reservoirs, an Example from the Molve Field, Croatian Pannonian Basin. Petroleum Geoscience, Vol. 16, No. 1, pp. 41-51, ISSN 1354-0793.

Middleton G.V. (1967). Experiments on density and turbidity currents: III. Deposition of sediment. Canadian Jour. Earth Sci., Vol. 4, No. 3, pp. 475-505, ISSN 0008-4077.

Mitchum, R.M. Jr. (1977). Glossary of terms used in seismic stratigraphy, In: Seismic Stratigraphy-Applications to Hydrocarbon Exploration, U. Payton (Ed.), AAPG Memoir, Vol. 26, pp. 205-212, ISBN 0891813020, Tulsa, USA.

Odin, S.G. \& Matter, A. (1981). De glauconiarum origine. Sedimentology. Vol. 28, No. 5, pp. 611-641, ISSN 0037-0746.

Pamić, J. (1997). Vulkanske stijene Savsko-dravskog međuriječja i Baranje (Hrvatska) [Volcanic rocks in Sava-Drava inter-river area and Baranja (Hrvatska)] (in Croatian). Nafta, special issue, 192 p., ISSN 0027-755X.

Pavelić, D. (2001). Tectonostratigraphic model for the North Croatian and North Bosnian sector of the Miocene Pannonian Basin System. Basin Research, Vol. 13, (September 2001), No. 3, pp. 359-376.ISSN 0950-091X.

Pavelić, D. (2002). The south-western boundary of Central Paratethys. Geologia Croatica, Vol. 55, No. 1, pp. 83-92, ISSN 1330-030X.

Pletikapić Ž. (1965). Stratigrafija, paleogeografija i naftoplinonosnost Ivanić - Grad formacije na obodu Moslavačkog masiva [Stratigraphy, Palaeogeography and Hydrocarbon Potential of Ivanić-Grad formation on the margin of the Moslavačka gora Mt.] (in 
Croatian). PhD Thesis, Faculty of Mining, Geology and Petroleum Engineering, University of Zagreb.

Pirson S.J. (1970). Geologic well log analysis (1st edition). Gulf Publ. Co., ISBN 0-87201-901-2, Houston.

Rögl, F. (1996). Stratigraphic correlation of the Paratethys Oligocene and Miocene. Mitteilungen der Gesellschaft der Geologie- und Bergbaustudenten in Wien, Vol. 41, (annually), pp. 65-73, 1 tab., ISSN 0435-8104.

Rögl, F. (1998). Palaeographic consideration for Mediterranean and Paratethys Seaways (Oligocene to Miocene). Annalen des Naturhistorischen Museums in Wien, Vol. 99 (Serie A), (annually), pp. 279-310, ISSN 0255-0091.

Rögl, F. \& Steininger, F. (1984). Neogene Paratethys, Mediterranean and Indo-Pacific seaways, In: Fossils and Climate, P. J. Brenchey (Ed.), 352 p., Geological Journal special issue, no. 11, Wiley and Sons, pp. 171-200, ISBN 047190418X, Chichester, UK.

Royden, L. H. (1988). Late Cenozoic tectonics of the Pannonian Basin System, In: The Pannonian Basin, L.H. Royden and F. Horváth (Eds.), AAPG Memoir, Vol. 45, pp. 27-48, ISBN 0891813225, Tulsa, USA.

Šćavničar B. (1979). Pješčenjaci pliocena i miocena Savske potoline [Pliocene and Miocene sandstones of Sava depression] (in Croatian). 3rd annual scientifc meeting ZSN JAZU, Novi Sad, March 1977.

Šimon, J. (1980). Prilog stratigrafiji u taložnom sustavu pješčanih rezervoara Sava-grupe .naslaga mlađeg tercijara u Panonskom bazenu sjeverne Hrvatske [Contribution to stratigraphy in depositional system of sandstone reservoirs of the Sava Group of Late Tertiary sediments in Pannonian basin of Northern Croatia] (in Croatian). PhD Thesis, Faculty of Mining, Geology and Petroleum Engineering, University of Zagreb.

Tišljar, J. (1993). Sedimentary bodies and depositional models for the Miocene oil-producing areas of Ladislavci, Beničanci and Obod. Nafta, Vol. 44, No. 10, pp. 531-542, ISSN 0027-755X.

Troskot-Čorbić, T., Velić, J. \& Malvić, T. (2009). Comparison of the Middle Miocene and the Upper Miocene source rock formations in the Sava Depression (Pannonian Basin, Croatia). Geologia Croatica, Vol. 62, No. 2, pp. 123-133, ISSN 1330-030X.

Velić, J. (2007). Geologija ležišta nafte i plina [Geology of oil and gas reservoirs] (in Croatian). ISBN 978-953-6923-10-6, Faculty of Mining, Geology and Petroleum Engineering, University of Zagreb.

Velić, J., Malvić, T., Cvetković, M. \& Vrbanac, B. (2010). Characteristics of Hydrocarbon Fields in the Croatian Part of the Pannonian Basin. Oil Gas European Magazine, Vol. 36, No. 3, pp. 146-147, ISSN 0342-5622.

Velić, J., Malvić, T., Cvetković, M., Weisser, M. \& Curi, V. (2008). Observation useful for increase of hydrocarbon fields exploitation period within Croatian part of the Pannonian basin. Proceedings of SGEM conference "Modern Management of Mine Producing Geology and Environmental Protection". ISBN 954918181-2, Albena, Jun 2008.

Velić, J., Weisser, M., Saftić, B., Vrbanac, B. \& Ivković, Ž. (2002). Petroleum-geological characteristics and exploration level of the three Neogene depositional megacycles in the Croatian part of the Pannonian basin (in Croatian). Nafta, Vol. 53, No. 6-7, pp. 239-249, ISSN 0027-755X. 
Vrbanac, B. (1996). Paleostrukturne i sedimentološke analize gornjopanonskih naslaga formacije Ivanić grad u Savskoj depresiji [Palaeostructural and sedimentological analysis of the Upper Pannonian deposits of the Ivanic Grad Formation in the Sava depression] (in Croatian). PhD Thesis, Faculty of Natural Sciences, University of Zagreb.

Vrbanac, B. (2002). Facies and facies architecture of the Ivanic Grad Formation (late Pannonian)-Sava Depression, NW Croatia. Geologia Croatica, Vol. 55, No. 1, pp. 57-77, ISSN 1330-030X.

Vrbanac, B., Velić J. \& Malvić T. (2010). Sedimentation of deep-water turbidites in main and marginal basins in the SW part of the Pannonian Basin. Geologica Carpathica, Vol. 61, No. 1, pp. 55-69, ISSN 1335-0552.

Vrsaljko, D., Pavelić, D., Miknić, M., Brkić, M., Kovačić, M., Hećimović, I., Hajek-Tadesse, V., Avanić, R. \& Kurtanjek, N. (2006). Middle Miocene (upper Badenian/Sarmatian) palaeoecology and evolution of the environments in the area of Medvednica Mt. (North Croatia). Geologia Croatica, Vol. 59, (December 2006), No. 1, pp. 51-63, ISSN 1330-030X.

Walker R. G. (1978). Deep-water sandstone facies and ancient submarine fans; model for exploration for stratigraphic traps. Bulletin of Am. Assoc. Petroleum Geologists, Vol. 62, No. 6, pp. 932-966, ISSN 0149-1423.

Yilmaz, P. O., Norton, I. O., Chuchla, R. J. \& Leary, D. A. (1996). Tectonic evolution and paleogeography of Europe, In: Peri-Tethys memoir 2: structure and Prospects of Alpine Basins and Forelands, P.A. Ziegler and F. Horváth (Eds.), Mémoires du Muséum National d'Histoire Naturelle, Vol. 170, pp. 47-60, ISBN 2-85653-507-0, Paris, France. 


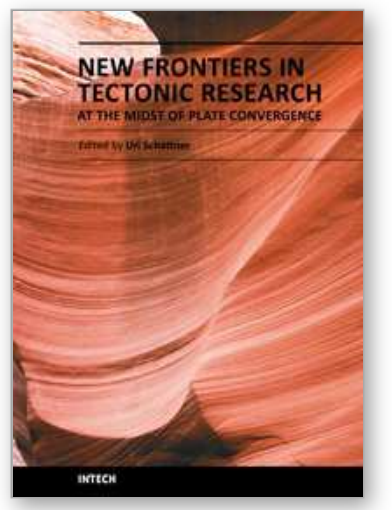

\section{New Frontiers in Tectonic Research - At the Midst of Plate Convergence}

Edited by Dr. Uri Schattner

ISBN 978-953-307-594-5

Hard cover, 352 pages

Publisher InTech

Published online 09, August, 2011

Published in print edition August, 2011

Ocean closure involves a variety of converging tectonic processes that reshape shrinking basins, their adjacent margins and the entire earth underneath. Following continental breakup, margin formation and sediment accumulation, tectonics normally relaxes and the margins become passive for millions of years. However, when final convergence is at the gate, the passive days of any ocean and its margins are over or soon will be. The fate of the Mediterranean and Persian Gulf is seemingly known beforehand, as they are nestled in the midst of Africa-Arabia plate convergence with Eurasia. Over millions of years through the Cenozoic era they progressively shriveled, leaving only a glimpse of the Tethys Ocean. Eventually, the basins will adhere to the Alpine-Himalaya orogen and dissipate. This book focuses on a unique stage in the ocean closure process, when significant convergence already induced major deformations, yet the inter-plate basins and margins still record the geological history.

\section{How to reference}

In order to correctly reference this scholarly work, feel free to copy and paste the following:

Tomislav Malvić and Josipa Velic (2011). Neogene Tectonics in Croatian Part of the Pannonian Basin and Reflectance in Hydrocarbon Accumulations, New Frontiers in Tectonic Research - At the Midst of Plate Convergence, Dr. Uri Schattner (Ed.), ISBN: 978-953-307-594-5, InTech, Available from: http://www.intechopen.com/books/new-frontiers-in-tectonic-research-at-the-midst-of-plateconvergence/neogene-tectonics-in-croatian-part-of-the-pannonian-basin-and-reflectance-in-hydrocarbonaccumulatio

\section{INTECH}

open science | open minds

\section{InTech Europe}

University Campus STeP Ri

Slavka Krautzeka 83/A

51000 Rijeka, Croatia

Phone: +385 (51) 770447

Fax: +385 (51) 686166

www.intechopen.com

\section{InTech China}

Unit 405, Office Block, Hotel Equatorial Shanghai

No.65, Yan An Road (West), Shanghai, 200040, China 中国上海市延安西路65号上海国际贵都大饭店办公楼 405 单元 Phone: +86-21-62489820

Fax: $+86-21-62489821$ 
(C) 2011 The Author(s). Licensee IntechOpen. This chapter is distributed under the terms of the Creative Commons Attribution-NonCommercialShareAlike-3.0 License, which permits use, distribution and reproduction for non-commercial purposes, provided the original is properly cited and derivative works building on this content are distributed under the same license. 